\title{
PERNIKAHAN DINI DAN IMPLIKASINYA TERHADAP KEHIDUPAN KELUARGA PADA MASYARAKAT MADURA (PERSPEKTIF HUKUM DAN GENDER)
}

\author{
Umi Sumbulah \\ Faridatul Jannah \\ Fakultas Syariah UIN Maliki Malang
}

\begin{abstract}
Early marriage phenomenon in Madurese society is caused by parents' worry towards their children's behaviour, self readiness, reducing economic burden of the family, and less awareness of the importance of education. This sort of marriage implies on child care and the way the couple educate their child and tension within the marriage which is ended by divorce. People's perceptions on early marriage practice are categorized into proponent and opponent groups. The reasons for those who disagree with the marriage are couple's readiness in managing the family, couple's age maturity biologically, sociologically as well as psychologically which will influence family's life. By contrast, for those who agree with this early marriage, they propose that this marriage is practiced to save the religion and to avoid free sex. Besides, there are some parents who are proud if their children get married soon and not to be late age girl. Economic reason is another consideration for parents that the son in law will support them financially.
\end{abstract}

Fenomena pernikahan dini pada masyarakat Madura disebabkan adanya kekhawatiran orang tua terhadap perilaku anak, kesiapan diri, mengurangi beban ekonomi keluarga, dan rendahnya kesadaran terhadap pentingnya pendidikan. Implikasi pernikahan dini bagi kehidupan keluarga di antaranya pada pengasuhan dan pendidikan anak yang tidak maksimal, serta pertengkaran yang seringkali berakhir pada perceraian. Pandangan masyarakat tentang pernikahan dini, dapat diklasifikasikan pada dua kategori, kurang setuju dan setuju. Masyarakat yang kurang terhadap pernikahan dini, karena belum ada kesiapan mengelola rumah tangga. Usia yang belum matang secara biologis, sosiologis maupun psikologis, 
bisa berdampak kurang baik pada perjalanan keluarga yang dibangun kedua mempelai.Adapun masyarakat yang menyetujui pernikahan dini, beralasan bahwa jalan itu ditempuh semata-mata untuk menyelamatkan agama, menghindari pergaulan bebas dan perzinaan. Di samping itu ada sebagian orang tua yang merasa bangga jika anak perempuannya cepat menikah dan tidak menjadi perawan tua. Alasan ekonomi berupa upaya mengurangi beban orang tua karena dengan mendapatkan menantu berarti aset ekonomi yang menopang keluarga bertambah.

Keywords: pernikahan dini, keluarga, masyarakat Madura, hukum dan gender

\section{Pendahuluan}

Pernikahan merupakan hal yang penting, karena dengan pernikahan seseorang akan memperoleh keseimbangan hidup baik secara biologis, psikologis maupun secara sosial. Secara biologis, kebutuhan seksual terpenuhi. Secara psikologis, kemaatangan mental dan stabilitas emosi, juga turut menentukan kebahagaiaan hidup berumah tangga. Usia pernikahan yang terlalu muda dapat mengakibatkan meningkatnya kasus perceraian karena kurangnya kesadaran untuk bertanggung jawab dalam kehidupan berumah tangga. Secara sosiologis, pernikahan menjadikan sepasang lakilaki dinilai sah sebagai pasangan suami-istri dan sah secara hukum.

Pernikahan yang sukses sering ditandai dengan kesiapan suami istri dalam memikul tanggung-jawab. Begitu memutuskan untuk menikah, mereka harus siap menanggung segala beban yang timbul akibat pernikahan, terutama menyangkut pemberian nafkah, pendidikan dan pengasuhan anak. Dalam konteks pendidikan anak, usia seorang ibu yang terlalu muda dan kurang memiliki kesiapan lemalhirkan, bias sulit mendapatkan keturunan yang berkualitas. Kedewasaan seorang ibu, turut serta mempengaruhi perkembangan anak. Seorang ibu yang telah dewasa secara psikologis, secara umum akan lebih terkendali emosi maupun tindakannya terhadap anak-anaknya, dibandingkan dengan para ibu muda. Hal-hal semacam ini sangat berdampak pada pembentukan karakter anakanak yang dilahirkannya.

Selain mempengaruhi aspek fisik, umur ibu juga mempengaruhi aspek psikologi anak. Seorang ibu yang masih berusia remaja sebenarnya belum memiliki kesiapan menjadi ibu yang sesungguhnya, karena 
minimnya keterampilan mengasuh anak. Sifat-sifat ibu muda yang pada umumnya memiliki emosi yang kurang stabil, minimimnya kesiapan psikologis menghadapi dan menyelesaikan konflik-konflik yang dialami, akan sangat mempengaruhi perkembangan psikososial anak. Oleh sebab itu, sangat penting artinya memperhatikan umur seseorang yang akan menikah. Meskipun batas umur pernikahan telah ditetapkan dalam pasal 7 ayat 1 UU No. 1 Tahun 74, yaitu pernikahan hanya diijinkan jika pihak pria sudah mencapai umur 19 tahun dan pihak wanita sudah mencapai umur 16 tahun,(Soemiyati,1999), namun dalam praktiknya masih banyak dijumpai pernikahan pada usia muda atau di bawah umur.

\section{Pernikahan Dini dan Kehidupan Keluarga}

Pernikahan dini menurut Islam adalah pernikahan yang dilakukan orang yang belum baligh (mimpi basah) bagi laki-laki atau belum mendapat menstruasi pertama bagi perempuan. Sebagian ulama memperbolehkan pernikahan di bawah umur, dengan dalil: pertama, mengikuti sunnah rasul karena sejarah telah mencatat bahwa Aisyah dinikahi oleh Nabi Muhammad pada usia 6 tahun sedangkan Muhammad telah berusia 50-an tahun; kedua, pernikahan dini dinilai dapat mempertahankan norma-norma agama berupa menghindarkan pasangan muda-mudi dari dosa akibat pergaulan bebas dan perzinaan, sehingga sebagian orang mengartikan bahwa tujuan pernikahan adalah menghalalkan hubungan seks.http://www.isadanislam. com/ulasan-berita-agama/145)

Indraswari memberikan batasan kawin muda adalah perkawinan yang dilakukan sebelum usia 16 tahun bagi perempuan dan 19 tahun bagi laki-laki. Batasan usia ini mengacu pada ketentuan formal batas minimum usia menikah yang berlaku di Indonesia (Syafiq Hasyim 31). Sarlito Wirawan Sarwono mengartikan pernikahan dini sebagai sebuah nama yang lahir dari komitmen moral dan keilmuan yang sangat kuat, sebagai sebuah solusi alternatif. Batas bawah usia dewasa bagi laki-laki 25 tahun dan bagi perempuan 20 tahun. Dengan demikian, batasan usia pernikahan di bawah umur itu ketika terjadi pernikahan antara seorang laki-laki yang berusia kurang dari 25 tahun dan kurang dari 20 tahun bagi perempuan. (http://nyna0626.blogspot)

Pernikahan dini merupakan fenomena yang juga terkait erat dengan nilai-nilai sosial budaya dan agama yang hidup dalam masyarakat. 
Dalam konteks Indonesia pernikahan lebih condong diartikan sebagai kewajiban sosial dari pada manifestasi kehendak bebas setiap individu. Secara umum dapat diajukan sebuah hipotesa bahwa dalam masyarakat yang pola hubungannya bersifat tradisional, pernikahan dipersepsikan sebagai suatu "keharusan sosial" yang merupakan bagian dari warisan tradisi dan dianggap sakral. Sedangkan dalam masyarakat rasional modern, perkawinan lebih dianggap sebagai kontrak sosial, dan karenanya pernikahan sering merupakan sebuah pilihan. Cara pandang tradisional terhadap perkawinan sebagai kewajiban sosial ini, tampaknya memiliki kontribusi yang cukup besar terhadap fenomena kawin muda yang terjadi di Indonesia.( Syafiq Hasyim)

Dari segi psikologi, sosiologi maupun hukum Islam pernikahan dini terbagi menjadi dua kategori; pertama, pernikahan dini asli yaitu pernikahan di bawah umur yang benar murni dilaksanakan oleh kedua belah pihak untuk menghindarkan diri dari dosa tanpa adanya maksud sematamata hanya untuk menutupi perbuatan zina yang telah dilakukan oleh kedua mempelai; kedua, pernikahan dini palsu yaitu pernikahan di bawah umur yang pada hakekatnya dilakukan sebagai kamuflase dari moralitas yang kurang etis dari kedua mempelai. Pernikahan ini dilakukan hanya untuk menutupi perzinaan yang pernah dilakukan oleh kedua mempelai dan berakibat adanya kehamilan. Ketika terjadi fenomena pernikahan seperti ini, tampaknya antara anak dan kedua orang tua bersama-sama melakukan semacam "manipulasi" dengan cara melangsungkan pernikahan yang mulia dengan maksud untuk menutupi aib yang telah dilakukan oleh anaknya.

Pernikahan bukanlah semata untuk memenuhi kebutuhan biologis, akan tetapi ia merupakan suatu bentuk peribadatan mulia yang diridhai oleh Allah dan Rasul-Nya. Tujuan pernikahan akan terwujud jika di antara kedua belah pihak sudah memiliki kesiapan biologis, psikologis dan ekonomi. Dengan kemampuan tersebut maka akan membantu terciptanya hubungan yang harmonis, saling menolong dalam memenuhi hak dan kewajiban, saling menasehati, saling melengkapi, dan saling menjaga antara satu dengan yang lain (to care each other).

\section{Pernikahan Dini Perspektif Fiqih dan Undang-undang}

Secara umum, usia matang untuk memasuki dunia perkawinan adalah kematangan biologis, psikologis, dan ekonomis. Kematangan bio- 
logis dalam konteks fiqih dipahami oleh para ulama dengan mengukur usia taklif, yakni telah keluar mani/mimpi basah bagi laki-laki dan telah mendapat menstruasi/haidh bagi perempuan.( Muhammad Ali Assayis, Bandung, 1963). Sedangkan kematangan psikologi bisa diukur melalui pola-pola sikap, pola perasaan, pola pikir dan pola perilaku tampak, misalnya emosionalitas stabil, citra diri dan sikap pandangan lebih realistis, menghadapi masalah secara tenang dan sebagainya (Andi Mappiare, Suranaya,1982,36-40). Kesiapan ekonomis adalah kemampuan atau kepemilikan harta yang akan dijadikan modal bagi pasangan tersebut untuk mengarungi bahtera rumah tangga, yang membutuhkan biaya hidup yang tidak sedikit. Oleh karena ikatan dalam perkawinan akan membentuk komunitas baru berikut aturan-aturan menyangkut hak dan kewajiban, maka masing-masing pihak juga harus sadar akan tugas dan kewajibannya, toleran dengan pasangan hidupnya, sehingga terwujud suatu keluarga yang sakinah, mawaddah, warahmah.

Pasal 7 ayat (1) Undang-undang Perkawinan No. 1/1974 sebagai hukum positif yang berlaku di Indonesia, menetapkan bahwa batas umur perkawinan bagi laki-laki adalah 19 tahun dan bagi perempuan dan 16 tahun. Bahwa batas usia tersebut bukan merupakan batas usia seseorang telah cukup dewasa untuk bertindak, akan tetapi batas usia tersebut hanya merupakan batas usia minimal/batas bawah seseorang boleh melakukan pernikahan. Di dalam pasal 6 ayat (2), juga disebutkan bahwa seseorang sudah dikatakan dewasa kalau sudah mencapai umur 21 tahun, sehingga dalam melakukan pernikahan tidak perlu mendapatkan izin dari kedua orang tuanya.

Pasal 6 ayat 2 ini tampaknya sejalan dengan pemikiran Yusuf Musa yang berpendapat bahwa seseorang dikatakan sudah sempurna kedewasaannya setelah mencapai umur 21 tahun. Mengingat situasi dan kondisi zaman dengan segala problematikanya, juga mengingat pentingnya pernikahan di zaman modern, maka sebenarnya pernikahan memiliki implikasi tidak saja bagi pasangan suami-istri dan keluarga besarnya, namun juga memiliki keterkaitan dengan kehidupan masyarakat dalam arti yang lebih luas.

Jika dicermati seksama pasal-pasal yang ada dalam UU Nomor 1 tahun 1974 tersebut, batasan minimal usia pernikahan ini sesungguhnya tidak mengatakan bahwa pernikahan usia muda akan selalu berdampak 
negatif bagi pasangan tersebut, akan tetapi hanya merupakan upaya pemerintah untuk menghindari dampak yang kurang baik bagi pasangan yang menikah di usia yang terlalu muda. Namun juga tidak berarti bahwa pasangan yang telah berumur berarti pernikahannya akan baik-baik saja, tanpa ada masalah. Oleh karena itu, sebaiknya seseorang menikah jika ia telah memiliki kesiapan baik secara lahir maupun batin. Kesiapan dimaksud, tidak hanya bagi perempuan atau laki-laki saja, tetapi juga harus pada keduanya. Hal ini karena membangun keluarga sakinah hanya dapat diwujudkan ketika pasangan suami istri tersebut saling membatu, saling menopang, saling menguatkan dan saling mendukung, dalam pola relasi yang simetris, setara dan adil.dalam hal nini, berarti tidak ada dominasi apalagi subordinasi antara suami dan istri, yang dapat menyebabkan terjadinya kekerasan dari satu pihak kepada pihak lain, baik suami maupun istri.

\section{Penyebab dan Implikasi Pernikahan Dini bagi Kehidupan Keluarga}

Terjadinya pernikahan dini antara lain disebabkan faktor ekonomi dan sosial-budaya.(Syafiq Hasyim,143-144). Kondisi ekonomi yang kurang baik atau beban ekonomi yang berat karena anggota keluarganya banyak, menyebabkan seorang anak tidak mampu untuk melanjutkan pendidikan. Dalam situasi seperti ini, kawin muda merupakan mekanisme untuk meringankan atau mengurangi beban ekonomi mereka. Mengawinkan anak sedini mungkin berarti pula meringankan beban ekonomi keluarga, karena ada pemasukan finansial dari menantu yang bekerja membantu keluarga besar si perempuan.

Faktor sosial budaya juga memiliki peranan yang sangat besar untuk mendorong terjadinya pernikahan dini, karena ini adalah faktor pendorong tunggal yang tidak terkait dengan faktor ekonomi. Faktor sosial dimaksud adalah adanya praktik pembedaan perlakuan secara ekstrem antara anak laki-laki dan perempuan, adanya gabungan antara nilai-nilai sosial dan kesulitan ekonomi, adanya anggapan-anggapan tertentu tentang nilai keperawanan, desakan dari pihak orang tua, serta adanya nilai tentang harga perempuan, yakni pameo "makin tua makin tidak laku".(http//alfiyah23. student.umm.ac.id/) Faktor terakhir itu berkaitan erat dengan persoalan ketimpangan dan ketidakadilan dalam relasi gender yang berkembang di masyarakat. 
Menurut Akhmad Jayadiningrat, sebab-sebab utama terjadinya pernikahan dini adalah: pertama, adanya keinginan orang tua untuk segera mendapatkan tambahan anggota keluarga; kedua, tidak adanya pengertian mengenai akibat buruk perkawinan terlalu muda, baik bagi mempelai itu sendiri maupun keturunannya; ketiga, adanya sifat kolot orang Jawa yang tidak mau menyimpang dari ketentuan adat kebanyakan orang desa, yang mengatakan bahwa mereka mengawinkan anaknya begitu muda hanya karena mengikuti adat kebiasaan saja.

Selain faktor ekonomi dan budaya, pendidikan, kekhawatiran orang tua, media massa, dan adat juga menjadi faktor yang menyebabkan terjadinya perkawinan dini. Secara ekonomi, pernikahan dini terjadi karena keadaan keluarga yang hidup di garis kemiskinan, untuk meringankan beban orang tuanya maka anak wanitanya dikawinkan dengan orang yang dianggap mampu. Dalam konteks pendidikan, rendahnya tingkat pendidikan maupun pengetahuan orang tua, anak dan masyarakat, menyebabkan adanya kecenderungan mengawinkan anak yang masih dibawah umur. Sedangkan faktor yang juga signifikan akan terjadinya pernikahan dini adalah kekhawatiran orang tua terhadap perilaku anak-anaknya, dalam hal ini bertujuan untuk terhindar dari aib. Media massa juga memiliki kontribusi yang tidak kalah penting bagi terjadinya pernikahan dini. Gencarnya ekspose seks di media massa menyebabkan remaja modern kian permisif terhadap seks. Faktor lain adalah adat, yang memberikan nilai dan penghargaan yang rendah atau kurang sebanding dengan penghargaan yang diberikan kepada laki-laki.

Adapun implikasi pernikahan dini bagi keluarga adalah memiliki keterkaitan pada persoalan biologis, psikologis, sosial, dan perilaku seksual menyimpang. Pertama, secara biologis, alat-alat reproduksi anak masih dalam proses menuju kematangan sehingga belum siap untuk melakukan hubungan seks dengan lawan jenisnya, apalagi jika sampai hamil kemudian melahirkan. Ketidaksiapan organ reproduksi perempuan akan menimbulkan dampak yang berbahaya bagi ibu dan bayinya. Penelitian yang dilakukan oleh sejumlah perguruan tinggi dan LSM perempuan, bahwa dampak perkawinan di bawah umur di mana organ reproduksi belum siap untuk dibuahi, dapat memicu penyakit pada alat reproduksi perempuan, misalnya pendarahan terus-menerus, keputihan, infeksi, keguguran dan kemandulan. 
Usia ideal pembuahan pada organ reproduksi perempuan sekurangkurangnya adalah sejalan dengan usia kematangan psikologisnya, yakni usia 21 tahun, di mana seorang perempuan dipandang telah siap secara fisik dan mental untuk menjadi seorang ibu, yang dapat menerima kehadiran buah hati dengan segala kebahagiaan dan berbagai masalahnya.( Mufidah, Malang, 110). Kedua, secara psikologis, anak yang belum mencapai usia matang, sebenarnya juga belum memiliki kesiapan dan pemahaman yang memadai tentang hubungan seks, sehingga bisa menimbulkan trauma psikis berkepanjangan dalam jiwa anak yang sulit disembuhkan. Anak akan murung dan menyesali hidupnya yang berakhir pada perkawinan yang dia sendiri tidak mengerti atas putusan hidupnya. Selain itu, ikatan perkawinan akan menghilangkan hak anak untuk memperoleh pendidikan (wajib belajar 9 tahun), hak bermain dan menikmati waktu luangnya serta hak-hak lainnya yang melekat dalam diri anak.

Ketiga, secara sosiologis, fenomena pernikahan dini ini berkaitan dengan faktor sosial budaya dalam masyarakat patriarkhi yang bias gender, yang menempatkan perempuan pada posisi yang rendah dan hanya dianggap pelengkap seks laki-laki saja. Kondisi ini sangat bertentangan dengan ajaran agama apapun termasuk agama Islam yang sangat menghormati perempuan. Kondisi ini hanya akan melestarikan budaya patriarkhi yang bias gender, yang akan dapat memicu dan melahirkan kekerasan terhadap perempuan.

Keempat, secara seksual, pernikahan dini juga bisa berimplikasi pada adanya perilaku seksual yang menyimpang, yaitu perilaku yang gemar berhubungan seks dengan anak-anak yang dikenal dengan istilah pedophilia. Perbuatan ini jelas merupakan tindakan ilegal menggunakan seks anak, namun dikemas dalam "balutan" perkawinan yang seakanakan menjadi legal. Hal ini bertentangan dengan UU.No.23 tahun 2002 tentang Perlindungan Anak khususnya pasal 81, yang ancamannya berupa pidana penjara maksimum 15 tahun, minimum 3 tahun dan pidana denda maksimum 300 juta dan minimum 60 juta rupiah. Apabila tidak diambil tindakan hukum terhadap orang yang menggunakan seksualitas anak secara illegal, maka akan menyebabkan tidak adanya efek jera bagi pelaku, bahkan akan menjadi contoh yang tidak baik bagi yang lain.(Http// alfiyah23.student.umm.ac.id). 
Dari uraian tersebut, tampak bahwa implikasi pernikahan dini terhadap kehidupan keluarga begitu kompleks, lebih banyak mudharat dari pada manfaatnya. Orang tua yang menikahkan anaknya dalam usia dini, semestinya memahami peraturan perundang-undangan untuk melindungi anak (terutama anak perempuan) dari penderitaan hidup yang diakibatkan pernikahan dini tersebut. Menurut hasil penelitian yang dilakukan Indaswari, dampak pernikahan dini, ( Syafiq Hasyim,143-144) diantaranya adalah terjadinya pertengkaran dan percekcokan yang disebabkan oleh emosi masing-masing yang belum stabil sehingga mengakibatkan perceraian. Meskipun akhirnya menikah lagi, sesebanrnya perempuan tersebut juga akan memngalami masalah baru, terutama terkait dengan masalah kesehatan reproduksi.

\section{Fenomena Pernikahan Dini pada Masyarakat Madura}

Penelitian ini dilakukan di Desa Pandan Kecamatan Galis Kabupaten Pamekasan, yang didasarkan pada alasan bahwa di desa tersebut ditemukan masih banyak pernikahan dini pada beberapa pasangan. Jenis penelitian ini adalah penelitian sosiologis atau eksploratif, karena dilakukan dengan mencari gejala sosial.(J. Vredenbregt,Jakarta,33) Sumber data penelitian ini adalah tokoh masyarakat, pegawai KUA setempat, pelaku dan orang tua pelaku pernikahan dini. Di samping itu, literatur yang berkaitan dengan pernikahan dini menjadi sumber sekunder dalam penelitian ini. Pengumpulan data dilakukan dengan metode wawancara, observasi dan dokumentasi. Proses pengolahan data dilakukan melalui proses editing, classifying, verifying, dan concluding.

Pernikahan dini merupakan pernikahan yang dilakukan pada usia terlalu muda, sehingga tidak ada/kurang ada kesiapan biologis, psikologis maupun sosial. Fenomena pernikahan dini tersebut masih banyak terjadi di berbagai daerah, tak terkecuali di Pandan Galis Pamekasan Madura. Penyebab terjadinya pernikahan dini di wilayah ini dipengaruhi oleh berbagai faktor, di antaranya adalah rendahnya tingkat pendidikan yang mempengaruhi pola pikir mereka dalam memahami dan mengerti hakekat dan tujuan pernikahan, orang tua yang memiliki bebab psikologis jika anak perempuannya menjadi perawan tua (tidak laku-laku), faktor ekonomi maupun lingkungan tempat mereka tinggal juga bisa menjadi penyebab terjadinya pernikahan dini.(Ar, wawancara, Pamekasan, tanggal 07 Juli 
2010). Selain itu pernikahan dini juga bisa terjadi karena keinginan mereka untuk segera merealisasikan ikatan hubungan kekeluargaan antara kerabat mempelai laki-laki dan kerabat mempelai perempuan yang telah lama mereka inginkan.(Bn, wawancara, Pamekasan, tanggal 07 Juli 2010). Pada hampir setiap tahun, pernikahan dini terjadi di desa ini. Meskipun pada kenyataannya pasangan tersebut belum siap untuk menikah dan menjalani bahtera rumah tangga pada umur yang dibilang masih terlalu muda, pernikahan tetap dilangsungkan.

Terjadinya pernikahan dini di wilayah tersebut memiliki implikasi negatif bagi kehidupan pasangan yang telah melangsungkan pernikahan dini. Implikasi negative dimaksud adalah pertengkaran, percekcokan, dan bentrokan antara suami-istri. Emosi yang belum stabil, semakin rentan memicu konflik dan pertengkaran antara suami-istri. Di dalam rumah tangga, konflik dan pertengkaran sebenarnya merupakan pemandangan yang wajar, namun jika terjadi secara berkelanjutan, maka bisa mengakibatkan perceraian. (Sd, wawancara, Pamekasan, tanggal 08 Juli 2010) Ketika perceraian terjadi, yang yang kemudian menjadfi korban adalah perempuan dan anak-anak.

Masalah perceraian umumnya disebabkan masing-masing sudah tidak lagi memegang amanah sebagai istri atau suami. Istri sudah tidak menghargai suami sebagai kepala rumah tangga atau suami yang tidak lagi melaksanakan kewajibannya sebagai kepala rumah tangga. Apabila mereka mempertahankan ego masing-masing akibatnya adalah perceraian. Namun tidak mungkin dipungkiri bahwa tidak semua pernikahan dini berdampak kurang baik bagi sebuah keluarga karena tidak sedikit dari mereka yang telah melangsungkan pernikahan di usia muda dapat mempertahankan dan memelihara keutuhan keluarga sesuai dengan tujuan dari pernikahan itu sendiri.

\section{A. Penyebab Pernikahan Dini}

Penyebab terjadinya pernikahan dini di desa Pandan Kabupaten Pamekasan, adalah: pertama, kekhawatiran orang tua terhadap perilaku anak. Orang tua merupakan pendorong terjadinya pernikahan dini, dimana orang tua akan segera menikahkan anaknya jika sudah menginjak besar, hal ini merupakan hal yang sudah biasa atau turun-temurun. Sebuah keluarga yang mempunyai anak gadis tidak akan merasa tenang sebelum anak gadisnya menikah. Orang tua akan merasa takut apabila anaknya jadi perawan tua dan takut apabila anaknya akan melakukan ha-hal yang tidak 
diinginkan yang akan mencemari nama baik keluarganya. Masyarakat desa Pandan pada umumnya tidak menganggap penting masalah usia anak yang dinikahkan, karena mereka berpikir tidak akan mempengaruhi terhadap kehidupan rumah tangga mereka nantinya. Umur seseorang tidaklah suatu jaminan untuk mencapai suatu kebahagiaan, yang penting anak itu sudah aqil (baligh), aqil (baligh) bagi masyarakat desa Pandan ditandai dengan haid bagi perempuan berapapun umurnya, sedangkan bagi laki-laki apabila suaranya sudah berubah dan sudah mimpi basah. Jika orang tua sudah melihat tanda-tanda tersebut pada anaknya, maka orang tua segera mencari jodoh untuk anaknya, terutama orang tua anak gadis. Karena itu, banyak orang tua perempuan tidak bisa menolak lamaran seseorang yang datang untuk meminang anaknya meskipun anak tersebut masih kecil. Bahkan kebanyakan masyarakat desa Pandan, anak-anak yang masih berusia muda sudah bertunangan/ditunangkan.

Dalam kasus perjodohan, orang tua berperan lebih aktif, sehingga memberi kesan bahwa mencarikan jodoh bagi anaknya adalah merupakan tugas, tanggung jawab sekaligus hak yang sangat penting baginya. Perjodohan tersebut tidak selalu berjalan dengan baik. Banyak di antara anak-anak yang telah dijodohkan tersebut akhirnya menolak dan memberontak. Bahkan di antara mereka ada yang lari, untuk menentukan sikap dan pilihannya sendiri yang dianggapnya lebih baik. Kendati begitu, dengan berbagai cara orang tua berupaya mempertahankan ikatan pertunangan yang sudah bertahun-tahun dibina untuk untuk sampai ke pernikahan. Bahkan keinginan orang tua yang sangat kuat untuk mempertahankan ikatan pertunangan itu, terkadang ia mengambil jalan menyumpahi anak dan mengklaim anaknya sebagai anak durhaka dan tidak berbakti kepada orang tua. Oleh karena itu, tekadang anak dengan terpaksa menerima perjodohan, sehingga ia harus putus sekolah karena harus segera dikawinkan.(Ft, Wawancara, Pamekasan, tanggal 10 Agustus 2010)

Kedua, kesiapan diri. selain orang tua, pendorong terjadinya pernikahan dini di Desa Pandan disebabkan adanya kemauan diri sendiri dari pasangan. Hal ini disebabkan mereka sudah merasa bisa mencari uang sendiri dan juga pengetahuan anak yang diperoleh dari film atau mediamedia yang lain, sehingga bagi mereka yang telah mempunyai pasangan atau kekasih terpengaruh untuk melakukan pernikahan di bawah batas minimal usia perkawinan. 
Ketiga, mengurangi beban ekonomi keluarga. Adanya Pernikahan dini di Desa Pandan juga disebabkan kondisi ekonomi keluarga yang kurang mampu. Para orang tua yang menikahkan anaknya pada usia muda mengganggap bahwa dengan menikahkan anaknya, maka beban ekonomi keluarga akan berkurang satu. Hal ini disebabkan jika anak sudah menikah, maka akan menjadi tanggung jawab suaminya. Bahkan para orang tua juga berharap jika anaknya sudah menikah, maka akan dapat membantu kehidupan orang tuanya. Di desa Pandan Kecamatan Galis kabupaten Pamekasan, kondisi ekonomi setiap keluarga berbeda-beda. Tidak semua keluarga bisa memenuhi semua keperluan, karena penghasilan yang mereka peroleh belum bisa memadai untuk mencukupi kebutuhan seharihari. Diantara mereka ada yang memiliki pekerjaan tetap juga pekerjaan tidak tetap. Oleh karena itu untuk penghasilan yang mereka peroleh setiap harinya tidak menentu. Bagi orang-orang yang pekerjaannya tidak tetap, mereka akan kesulitan dalam menghidupi keluarganya.Lain halnya dengan orang yang telah memiliki pekerjaan tetap dan penghasilan yang tetap, maka segala kebutuhan sehari-harinya akan terpenuhi.

Keempat, rendahnya kesadaran terhadap pentingnya pendidikan. Rendahnya pendidikan juga merupakan pendorong terjadinya pernikahan dini. Para orang tua yang hanya bersekolah hingga tamat SD merasa senang jika anaknya sudah ada yang menyukai, dan orang tua tidak mengetahui adanya akibat dari pernikahan muda ini. Disamping perekonomian yang kurang serta pendidikan orang tua yang rendah, akan membuat pola pikir yang sempit. Sehingga akan mempengaruhi orang tua untuk segera menikahkan anak perempuannya.

\section{B. Implikasi Pernikahan Dini bagi Kehidupan Keluarga}

Pernikahan dini di desa Pandan Kecamatan Galis Kabupaten Pamekasan, mempunyai implikasi dan dampak yang kurang baik pada pasangan suami istri tersebut. Tidak jarang dari mereka yang melangsungkan pernikahan dini, tidak begitu memikirkan dampak yang akan timbul setelah mereka hidup berumah-tangga di kemudian hari. Mereka hanya memikirkan bagaimana caranya agar bisa segera hidup bersama dengan pasangannya tanpa memikirkan apa yang akan terjadi setelah hidup bersama.

Tidak bisa dipungkiri bahwa pada pasangan yang telah melangsungkan pernikahan dini tidak bisa memenuhi atau tidak mengetahui 
hak dan kewajibannya sebagai suami istri. Hal tersebut timbul dikarenakan belum adanya kematangan fisik maupun mental keduanya sehingga egoisme masing-masing sangat tinggi. Pernikahan dini bias menimbulkan berbagai persoalan rumah-tangga seperti pertengkaran, percekcokan dan konflik berkepanjangan, yang dapat mengakibatkan perceraian.

Dari para informan juga didapatkan data bahwa banyak orang yang telah melangsungkan pernikahan akan tetapi tidak begitu memikirkan implikasi dan dampak yang mungkin terjadi setelah menjalani hidup sebagai pasangan suami-istri khususnya bagi pasangan yang menikah dini, maupun bagi anak-anaknya.( Mh, wawancara, Pamekasan, tanggal 14 Agustus 2010). Hal ini karena orang tua adalah role model bagi anakanaknya. Seorang ayah yang sering memukul ibunya, maka perilaku tersebut dikonstruksi oleh si anak, sehingga menginternalisasi dan membentuk kepribadiannya. Jika ia menikah, maka tidak mustahil ia juga memperlakukan istrinya sebagaimana yang pernah dilakukan oleh ayah terhadap ibunya. Dengan demikian, kekerasan tersebut berlanjut, berlapis dan berkembang menjadi semacam suatu sistem dan nilai hidup dalam keluarga tersebut. Di samping berdampak bagi pasangan suami istri dan anak-anak, pernikahan dini juga bisa berimplikasi bagi perempuan yang melangsungkan pernikahan dini, berupa kemungkinannya untuk mengalami gangguan-gangguan pada kandungan dan alat reproduksinya, yang dapat membahayakan kesehatan bagi si ibu maupun si anak.

Selain itu, dampak negatif pernikahan dini juga bisa terjadi pada orang tua dan keluarga masing-masing. Apabila pernikahan diantara anakanak mereka lancar dan keluarganya baik-baik saja, maka kedua orang tua mereka akan merasa senang dan bahagia. Namun apabila pernikahan tersebut diwarnai konflik dan pertengkaran sehingga berujung kegagalan karena harus bercerai, maka mereka juga akan merasa sedih dan kecewa. Hal ini juga bisa berimplikasi pada ketidakharmonisan hubungan keluarga besar masingmasing pasangan tersebut. Kegagalan pernikahan anak-anak mereka bisa menjadi penyebab terputusnya silaturahmi di antara keluarga tersebut.

Akibat tidak adanya kecocokan, keharmonisan dan kurangnya pengertian antara suami-istri dalam menjalankan bahtera rumah tangga, memberikan pengaruh yang besar terhadap perkembangan anak-anaknya serta mempengaruhi tingkat kecerdasan dan juga rentannya gangguan- 
gangguan pada fisik sianak. Pernikahan dini merupakan suatu bentuk pernikahan yang tidak sesuai dengan yang diidealkan oleh Undangundang yang memberikan batasan minimal usia seseorang dapat melangsungkan pernikahan. Dengan kata lain, pernikahan dini merupakan bentuk penyimpangan dari pernikahan secara umum karena tidak sesuai dengan syarat-syarat pernikahan yang telah ditetapkan. Secara sederhana, dapat dikatakan bahwa pernikahan dini mengakibatkan sulitnya untuk mewujudkan tujuan pernikahan yang sakinah, mawaddah dan warrahmah, apabila dibandingkan dengan pernikahan yang dilaksanakan sesuai dengan syarat dan ketentuan yang telah ditetapkan perundang-undangan. Hal ini tidak berarti bahwa pernikahan dini dapat dipastikan tidak akan dapat mewujudkan tujuan pernikahan, karena pernikahan yang memenuhi persyaratan usia pun pada kenyataannya tidak semuanya dapat mewujudkan tujuan ideal pernikahan sebagaimana yang disebutkan di atas. Namun penting diingat bahwa keluarga yang sering mengalami konflik dan pertengkaran, merupakan potensi negatif bagi penciptaan keluarga sakinah, mawaddah warahmah. Dengan kata lain, pernikahan dini memiliki resiko lebih besar untuk gagal dibandingkan dengan pernikahan yang telah memenuhi persyaratan perundangan. Pernikahan dini tidak hanya dapat berakibat negatif terhadap kedua belah pihak, tetapi juga berdampak pada anak, keluarga besar dan masyarakat.

Pengetahuan tentang pola pengasuhan dan pendidikan anak, merupakan problema tersendiri bagi pasangan usia nikah dini. Di antara mereka banyak yang menyerahkan anak-anaknya untuk diasuh orang tuanya (kakek-neneknya) daripada diasuh sendiri, karena mereka sendiri masih terlalu muda untuk merawat anak.

Persoalan lainnya adalah menyangkut penyelesaian masalah yang terjadi dalam keluarga. Di antara mereka ada yang menyelesaikan sendiri, tapi ada juga yang secara keluarga dan ada juga yang memerlukan bantuan pihak ketiga. Dari 13 informan, 9 informan menyelesaikan sendiri masalah keluarga yang dialaminya, dan 4 informan lainnya menyelesaikan masalah dengan bantuan pihak ketiga, yaitu orang tua mereka sendiri. Secara ekonomi, mereka masih menggantungkan pemenuhan kebutuhan ekonomi kepada orang tua karena mereka belum bekerja. 
Menurut beberapa data yang peneliti peroleh dari pendapat masyarakat, dapat diperoleh kesimpulan bahwa pernikahan dini masih terjadi, akan tetapi mengalami penurunan dari tahun ketahun. Hal itu karena masyarakat sudah mulai mengerti dan pemikirannya sudah mulai berkembang. Hal ini di antarana terbukti dengan banyaknya anak yang melanjutkan studi atau pendidikan hingga sekolah menengah atas, bahkan ada pula yang melanjutkan studi di perguruan tinggi.

Hasil penelitian ini menyebutkan bahwa sebenarnya jika pendidikan orang tua meningkat dan memikirkan dampak negatif yang terjadi pada anak yang menikah di usia dini, maka pernikahan di usia dini itu tidak akan terjadi begitu banyak. Beberapa hasil observasi yang kami dapat menyatakan bahwa pendorong terjadinya pernikahan dini adalah keinginan orang tua, sebab keinginan orang tua menikahkan anaknya adalah hal yang penting karena dikhawatirkan akan terjadi hal yang tidak diinginkan, tetapi alasan itu juga tidak dibenarkan oleh sebagian masyarakat, karena bagi sebagian mereka menikahkan anaknya di usia muda itu disebabkan faktor ekonomi. Dalam hal memilih pasangan ini, orang tua dilarang memaksa anak-anaknya untuk dijodohkan dengan pria atau wanita pilihannya, melainkan diharapkan membimbing anak-anaknya agar dapat memilih pasangan yang sesuai dengan ajaran agama.

Dan ada pula yang menyatakan bahwa dampak anak yang dinikahkan diusia dini adalah dampak psikologi, jika anak dinikahkan dibawah umur maka dalam menjalani kehidupan rumah tangga tidak akan harmonis, mereka lebih sering bertengkar dan akhirnya terjadi perceraian, sebab emosi dan pemikiran mereka belum siap. Dan usia matang atau kesiapan umur secara psikologi adalah usia bagaimana kita perpola sikap, pola perasaan, pola pikir dan prilaku sehingga pasangan tersebut mampu menjaga egoisme serta sikap dalam rumah tangga dan disanalah terjalin pasangan yang harmonis.(Andi Mappiare, Psikologi Remaja, 36-40)

Selain implikasi psikologis, ada pula dampak yang harus diperhatikan bagi tiap orang tua terhadap anaknya yaitu dampak biologis, sebab anak yang belum cukup usia maka organ reproduksinya belum siap dibuahi, karena masa-masa itu adalah masa proses menuju kematangan. Jika anak dipaksa menikah di usia dini, maka hal itu bisa membahayakan nyawa ibu dan bayi, seperti paparan sebelumnya.( Mufidah, 110) 
Implikasi lainnya adalah pada kelangsungan hidup rumah tangga pasangan usia dini tersebut. Pada masyarakat Pandan, tampaknya tidak banyak orang tua yang menyesal telah menikahkan anak-anaknya di usia dini. Padahal mereka sering melihat bahtera rumah tangga anaknya yang sering diwarnai konflik dan pertengkaran karena persoalan sepele, yang bisa jadi akan berujung perceraian. Data yang peneliti temukan tentang beberapa implikasi pernikahan dini di antaranya adalah bahtera rumah tangga mereka tidak hamonis, sering bertengkar, pisah ranjang bahkan sampai bercerai. Hal ini semestinya tidak harus terjadi jika orang tua dan anak-anak memiliki pengetahuan yang memadahi tentang makna sebuah pernikahan. Tampaknya fenomena yang tejado di Pandan ini, senada dengan hasil penelitian Indaswari, yang menyatakan bahwa dampak dari pernikahan dini adalah pertengkaran dan percekcokan yang disebabka oleh emosi masingmasing yang belum stabil, berakibat perceraian meski akhirnya menikah lagi, berdampak pada masalah kesehatan seksual dan kesehatan reproduksi bagi perempuan, sehingga menghilangkan kesempatan bagi mereka untuk menempuh pendidikan yang lebih tinggi. (Syafiq Hasyim,143-144).

Sebenarnya masyarakat Pandan sendiri tidak seluruhnya setuju dengan praktik pernikahan dini. Di antara mereka juga ada yang tidak setuju. Pertama, masyarakat yang tidak setuju dengan pernikahan dini, beranggapan bahwa usia yang belum matang disertai cara berfikir yang masih seperti anak-anak, bisa berakibat pada tidak ditemukannya solusi atas konflik yang terjadi. Walaupun secara agama pernikahan dini diperbolehkan, namun alangkah lebih baik jika pernikahan itu dilakukan pada usia yang sudah matang.(Fathol Mu'in, wawancara, Pamekasan, 20 Agustus 2010) Di samping itu, pernikahan dini dikhawatirkan juga berdampak pada masalah kesehatan, karena hamil pada umur yang masih muda berabahaya bagi kandungan dan proses bersalin.

Rendahnya tingkat pendidikan juga merupakan alasan lain ketidaksepakatan masyarakat terhadap pernikahan dini. Mereka beranggapan bahwa, kebanyakan dari mereka yang melakukan pernikahan dini adalah mereka yang berpendidikan rendah, sehingga jika berkeluarga mereka belum mampu mengasuh dan memberikan pendidikan pada anaknya (Rabi'i, wawancara, Pemekasan, 23 Agustus 2010). 
Kedua, masyarakat yang setuju dengan pernikahan dini. Alasan yang diajukan adalah bahwa pernikahan itu terjadi semata-mata karena untuk menyelamatkan agama, karena agama membolehkan menikah apabila sudah baligh, dan apa yang ditentukan agama pasti baik untuk umatnya. Mereka juga mengatakan bahwa pernikahan dini merupakan suatu kebanggaan, karena anaknya cepat laku dan tidak menjadi beban orang tua, bahkan bisa membantu ekonomi orang tua. Dengan demikian, pernikahan dini tampaknya juga sudah menjadi sebuah tradisi yang melekat pada masyarakat Madura.(Sa'id, wawancara, Pamekasan 22 Agustus 2010).

Kemiskinan juga menjadi salah satu penyebab terjadinya pernikahan dini. Untuk meringankan beban ekonomi orang tua, maka anak perempuan dinikahkan dengan orang yang dianggap memiliki kemampuan ekonomi yang lebih tinggi. (http//alfiayah23. Student.umm.ac.id/) Namun demikian, fenomena pernikahan dini juga berkaitan dengan faktor sosial budaya dalam masyarakat patriarkhi, yang menempatkan perempuan pada posisi yang rendah dan dianggap sebagai pelengkap bagi laki-laki saja. Kondisi ini tentu bertentangan dengan ajaran agama Islam yang sangat menghormati perempuan, sebab hal ini juga bisa mengakibatkan terjadinya kekerasan terhadap perempuan.

\section{Penutup}

Pendorong terjadinya pernikahan dini di Pandan Madura, di antaranya adalah: pertama, adanya kekhawatiran orang tua terhadap perilaku anak. Kekhawatiran orang tua menjadi pendorong terjadinya pernikahan dini, disebabkan takut akan terjadi hal-hal yang tidak diinginkan dan ketakutan anaknya tidak laku atau menjadi perawan tua. Oleh sebab itu, adalah sebuah kebanggaan jika orang tua bisa menikahkan anaknya dalam usia yang relatif muda, karena anak yang sudah menikah diyakini akan membawa berkah bagi keluarga. Kedua, adanya kesiapan diri. Mereka yang sudah merasa mampu untuk membangun rumah tangga dan menafkahi, maka ia akan segera menikah meski usianya belum cukup matang. Ketiga, mengurangi beban ekonomi keluarga, merupakan harapan bagi orang tua yang secara ekonomi miskin. Dengan menikahkan anak gadisnya, maka beban ekonomi keluarga menjadi berkurang dan diharapkan anaknya yang telah menikah juga dapat membantu ekonomi orang tuanya. Keempat, 
rendahnya tingkat kesadaran terhadap pentingnya pendidikan, baik pendidikan baginya maupun bagi anak-anak yang dilahirkannya kelak.

Adapun implikasi yang timbul dari pernikahan dini bagi pasangan suami istri ini di antaranya adalah terjadinya pertengkaran dan percekcokan dalam rumah tangga, yang tidak jarang berujung dengan perceraian. Di samping itu, implikasi secara lebih luas menyeruak ke keluarga besar dari pasangan suami istri tersebut. Jika perkawinan anak-anaknya tidak harmonis, sering terjadi pertengkaran bahkan berujung perceraian, maka orang tua akan kecewa, bahkan bisa berakibat putusnya tali silaturrahim di antara kedua keluarga besar tersebut.

\section{DAFTAR PUSTAKA}

Al-Shabuni, Ali. Pernikahan Islam.Solo: penerbit Mumtaza, 2008.

Asmin. Status Peerkawinan Antar Agama Tinjauan dari Undang-undang Perkawinan No.1/1974.Jakarta: PT Dian Rakyat, 1986.

Athif, Lamadah. Fiqih Sunnah Untuk Remaja.Jakarta: Cendekia Sentra Muslim, 2007.

Amiur, Nuruddin dan Azhari Akmal Tarigan. Hukum Perdata Islam di Indonesia Studi Kritis Perkembangan Hukum Islam dari Fiqih, UU 1/1974 sampai KHI.Jakarta: Kencana, 2006.

Ayyub, Syaikh Hasan. Fiqih Keluarga.Jakarta: Pustaka Al-Kautsar, 2001.

Al-Sayis, Muhammad Ali. Tafsir Ayat AlAhkam Al Qur'an, terj. Muhammad Ali Sabiq.Bandung: As-Syifa, 1963.

Depag RI, Al-Qur'an dan Terjemahnya.Bandung : 2005.

Fachri A. Perkawinan Sex dan Hukum.Pekalongan: TB. \& penerbit Bahagia, 1986.

Fachruddin. Ensiklopedia Al-Qur'an.Jakarta: Rineka Cipta, 1992.

http://www.isadanislam.com/ulasan-berita-agama/145-pernikahan-dinidalam-islam, diakses 3 Agustus 2010.

http//www. Maraknya Pernikahan Dini.diakses pada tanggal 2 Agustus 2010. 
http//www.PernikahandiBawahUmurdiKalanganOrangSumatera, diakses pada tanggal 3 Agustus 2010.

http// alfiyah23.student.umm.ac.id/. Sebab-sebab pernikahan dini, diakses pada tanggal 10 Juli 2010.

Hasyim, Syafiq. Menakar Harga Perempuan. Bandung: Mizan, 1999.

Ichsan, Ahmad. Hukum Perkawinan bagi yang Beragama Islam, Suatu Tinjauan dan Ulasan secara Sosiologi Hukum.Jakarta: Pradia Paramita, 1986.

Idris Ramulyo. Hukum Perkawinan Islam suatu analisis undang-undang No:1 tahun 1974 dan Kompilasi Hukum Islam.Jakarta: Bumi Aksara, 1996.

J. Vredenbregt. Metode dan Teknik Penelitian Masyarakat. Jakarta: PT. Gramedia, 1978.

Mappiare, Andi. Psikologi Remaja.Surabaya: Usaha Nasional, 1982.

Moleong, Lexy J. Metodologi Penelitian Kualitatif. Bandung: Remaja Rosdakarya, 2002.

Mufidah. Psikologi Keluarga Islam Berwawasan Gender.Malang: UIN Malang Press, 2008.

Soemiyati, Hukum Perkawinan Islam dan Undang-Undang Perkawinan Yogyakarta: Liberty,1999.

Tihami, Sohari Sahrani. Fiqih Munakahat Kajian Fiqih Nikah Lengkap. Jakarta: Rajawali Pres, 2009.

Undang-undang Perkawinan di Indonesia dan Peraturan Pelaksanaan, No. 1/1974. Jakarta: Pradnya Paramita 1974.

Zainuddin, Ali. Hukum Perdata Islam di Indonesia.Jakarta: Sinar Grafika, 2006. 